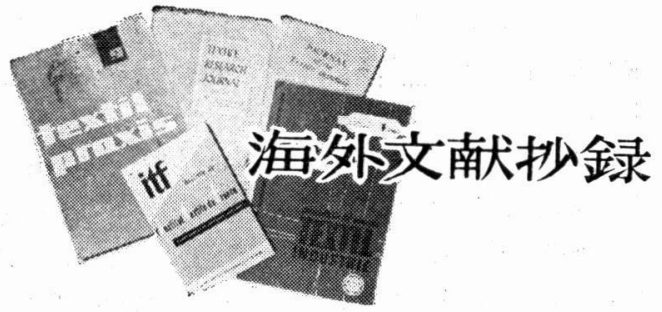

A. 織維ができるまで

緎維に対する熱の影響；J. W .S. Hearle, Skinn. Rec., 555〜558 (1966-8) <抄録 6, No. 12, 593 (1966)〉

2 種のポリマーからなる緎維; Skinn. Rec., 462 463 $(1966-7)<$ 抄録 6, No. 12, $593(1966)>$

宇宙時代の織維; M. J. Keating, Skinn. Rec., 561 $562(1966-8)<$ 抄録 6 , No. 12, 595 (1966)>

B. 紡できるきで

長縺維の短繊維紡績法; R. O. Perrault, Text. Ind., $81 \sim 84,94(1966-7)$ 〈抄録 6 , No. 12, 597 (1966)〉

靴下用梳毛糸の摩擦に対するワックスの 効果; D. Wilson 他, J. Text. Inst., T199〜 T216 (1966-5)

そ毛系々金属棒之の摩擦係数が糸に含杰れるワック スによってどのように影響されるかを論じている・ワ ックスの存在し\%い場合の糸之金属之の摩擦係数法約 0.32 であるが, ワックス含有量が増加すると急激に 摩擦係数は隇少し, $0.5 \mu \mathrm{g} / \mathrm{cm}$ のワックス含有量の とをに最小となり，それ以上にワックス含有量が多了 なると摩擦係数はやや大るなる。乙の極少になるワ ックス含有量治系の番手, 性質, 湿潤処理（染色, 漂 白，防縮加工など）に関係なくは快一定で $0.3 \sim 0.5$ $\mu \mathrm{g} / \mathrm{cm}$ である.

ワックスの存在しない場合には系速度に比例して摩 擦係数も増大するが, ワックスが存在するとその増加 率は低下し, 完全にワックスが付着した場合には速度 に関係なく一定になる. 金属表面る温度々摩擦係数々 の関係壮系速度によってかなり違って把り, 糸速度の 遅い々きには温度の上昇々ともに摩擦係数も隇少する が，糸速度が大きくなると區卧一定になる傾向がみら れる。

$<$ 篠原〉

糸や編物の伸縮性の不足に対しポリアミドとポリエ ステルの仮撚弾性糸におよばす加工条件の影響（第 2 報); J. Lünenschloss 他, Textil-Praxis, 317 321 $(196-5)<$ 抄録 6 , No. 11, $552(1966)>$

糸や編物の伸縮性の不足に対しポリアミドとポリエ ステルの仮撚弾性糸におよぼす加工条件の影響（第 3 報)；J. Lünenschloss 他, Textil-Praxis, 412 420 $(1966-6)<$ 抄録 6, No. 11，552（1966)>

合成織維 フィラメント糸の ラジアス クリンピングに よるパルキー加工について; J. Sykes 他, J.Text.

Inst., T225～T241 (1966-6)<抄録 6, No. 11, 552 (1966)>
新しいS K F ペンジュラム式ドラフト装置とその応用 分野; H. Rubisch, Textil-Praxis, 482 483(1966-7)

$\mathrm{SKF}$ K ンジュラムアーム式ドラフト装置の新製 品 PK 700 型法従米のPK 600 型のローラー ゲージ が固定式であったのが，ウェイティングフロントア 一ム办伸縮してローラー ゙ージが可变式になり, フ ロントトップローラーの荷重けアームの稼動状態で 単独に調整でをる方式となった。したがって毛紘と合 縅紡に兼用できる。

新製品は 4 種類で, PK 701 と PK 703 法仏式りン ゲ用であるが，後者せフロントとバックの最大ローラ ーゲージが小さい. PK 704 はフライヤーとリンが 精紡機用の\&の扎よび英式りング精紡機用の 2 種類に 分汃る。

前者はローラーグージをせまくするととがでさる のて太中番毛糸に適する。また P K 704 沬 P K 701, PK 703 にくらでーラーの荷重沈さい

$\mathrm{SKF}$ Kペジュラムアーム式ドラマト装置 PK 700 型のエレメント

\begin{tabular}{|c|c|c|c|c|c|}
\hline 型 & 式 & PK 701 & PK 703 & P K 704 & P K 704 \\
\hline \multicolumn{2}{|c|}{ 精 絞 機 の 型 } & \begin{tabular}{|l|} 
仏式 \\
リング|
\end{tabular} & \begin{tabular}{|c|} 
仏式 \\
リング|
\end{tabular} & $\begin{array}{l}\text { 粗絞機 リ } \\
\text { ング(太 } \\
\text { 中番手 } \\
\text { 糸用) }\end{array}$ & $\begin{array}{l}\text { 英式 } \\
\text { リング }\end{array}$ \\
\hline \multirow{3}{*}{$\begin{array}{c}\square \\
1 \\
5 \\
1 \\
ケ ゙ \\
1 \\
\vdots \\
(\mathrm{mm})\end{array}$} & $\begin{array}{l}\text { フロント〜 } \\
\text { ミドル } \\
\quad(\text { 最小 }) \\
\end{array}$ & 115 & 115 & 80 & 115 \\
\hline & $\begin{array}{l}\text { ミドル〜バ } \\
\text { ック(最小) }\end{array}$ & 75 & 75 & 83 & 77 \\
\hline & $\left|\begin{array}{r}\text { フロント〜 } \\
\text { バック } \\
\text { (最大) }\end{array}\right|$ & 329 & 264 & 329 & 329 \\
\hline \multirow{3}{*}{$\begin{array}{l}\text { ト } 1 \\
\% \bar{~} \\
\text { プ荷 } \\
\text { 重 } \\
(\mathrm{kg})\end{array}$} & フロント & $30 \sim 50$ & $30 \sim 50$ & $45 \sim 65$ & $45 \sim 65$ \\
\hline & ミドル & 12 & 12 & 18 & 18 \\
\hline & バッ ク & 25 & 25 & 42 & 42 \\
\hline
\end{tabular}

高速カード; M. Allen, Text. Ind., 70〜80 (1966-7) 〈抄録 6 ，No. 12，599 (1966)〉

回転フラット カード用改良供給方式; Text. Rec., 96 (1966-9)〈抄録 6, No. 12，600（1966)〉

スライバーの平均緎維表をきめる新しい方法; P. J. Kruger, Text. Res. J., 687〜691 (1966-8) 抄録 6 , No. 12, 600 (1966)>

アメリカにおける自動化紡績；Text. Rec., 66〜68 (1966-9)

今年 7 月 15 日に操業をはじめたアメリカ, Beaunit のCrinton 自動化綿紡工場（ノースカロライナ州） の紹介記事.

アメリカのポリエステルと綿混紡布の生産高は今年 4 月 65.8 百万 yd（昨年 4 月 46.3 百万yd）で昨年よ り約 $50 \%$ 増加しているが, まだ不足している.

そとで全米工場数 17 をつ合繊の大メーカーの 1 つである Beaunit 社は Crinton に400万ドル（14.4 億円）で工場を新設した。同工場は今後 10 年以上は 現有設備で操業できるように設計された。 
計画では建て坪 11 万 $\mathrm{ft}^{2} 22,176$ 鍾, 紡出糸は綿と 合瀻混紬系の $18 \sim 28 \mathrm{~S}$, 平均番手 $24 \mathrm{~S}$ のカード糸走 週当たり 136, $500 \mathrm{lb}$ 生産の予定.

設置䋘機けすへて Saco-Lowell 製で, Blendmaster（滑り移送給綿方式） 4 台，カード 8 台，第 1 上 仲間扎よび仕上げ練条機は各 5 台，Rovemaster（粗 紡機） 6 台，ツイン自動ドッファ一付きリング精紡機 66 台でリング直径 $2 \frac{1}{2} \mathrm{in,} \mathrm{リフト} 10 \mathrm{in}, 9,450 \mathrm{rpm}$ といわ机る。

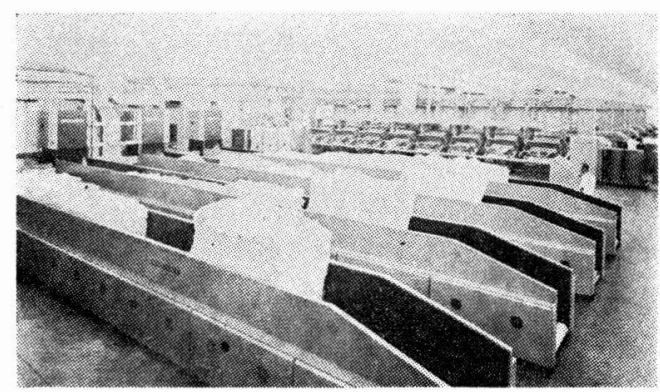

全景写 真

$\langle$ 武藤 $>$

\section{ら. 布ができるまで}

無ひ織機の現状；Text. World，48～73 (1966-8)

今日無ひ織機け世界各国で着実な発展を見せ，その 性能が改良されている・例えば種々の模様を表わすた めに，幾種類かのよて糸が供給できるようになり，ま た, 普通の織機に比較して生産速度は 2 倍で, 人造紻 維だけでなく，羊毛までも織布できる。織機自体，故 障しにくいので, 作業者 1 人当たり 80 台受け\&つとと が可能で, 製造された布の $98 \%$ 汕第 1 級品, 機械能 率は 96〜98\%とのととである。

以上の諸特性をもった無ひ織機は, 従来の織機に劣 らず重要な意味をもっている，そとで本報では，無ひ 織機の世界現状についてさすざ杂角度から述へてい る.まず，世界各国の無ひ織機19種について，ての特 長把よび, 技術面の発展過程について詳説し, つぎに アメリカ, ヨーロッパなどで実際に使用した結果につ いて 12 社の実例を報告している.

19 種の無ひ織機のうちわけは

レピア式（棒状） 6 ，レピア式（巻きとみ） 5 ，グ ワッパー3, ウォーター ジェット 2, ェヤー ジェッ ト 3 , で, ウォータージェットのなかにはわが国の プリンスウオータージェットもスっている.

このような 19 種の織機について, 製造会社, 織機 の名前, スピード, 把さ幅, 上と入れ方法, 上と糸の 種類, 耳など 10 項目についての一覧表がついている. <影斗〉

横編みの動力学, 数学的解析; J.J.F. Knapton, Text. Rec. 88，90，93 (1966-9) <抄録 6，No. 12，608 $(1966)>$

紡織素材プラスチック フィルム； Text. Rec., 88, $90,93(1966-9)<$ 抄録 6 , No. 12, 608 (1966)〉
完全自動式のたて糸のり付け；Text. World，84 - 87 (1966-8)

本方式住, Shirley Institute の Britain's Cotton, Silk \& Man-Made Fibers Research Association で開発され, Joseph Hibbert \& Co. Ltd. で特許に 基づき製作された．特長としては，綿扎よびその他の 紡績系に使用でき，生産速度は $130 \mathrm{rpm}$, 生産量は 1 $\mathrm{hr}$ 当たり $1500 \mathrm{lb}$ で, 仕上げ量江従来ののり付け機 と比較して 10 \% 増大している. 本報でけ, 一例とし て高浴織物製造会社の Dawes \& Co. (Nelson) Ltd. の実情をもととして, 性能, 特性などについて述へて いる。

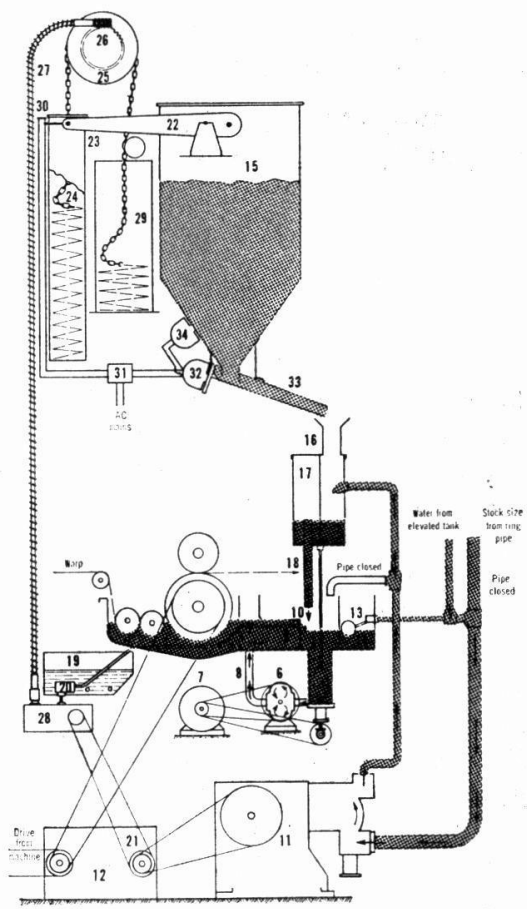

1. 糊箱作用部 2 . 混合箱 3 . 混合箱と作用部の接続部 4. 希䣋箱 5 . かく汇ん器 6 . ギャ一ポンプ 7. ギャ 一ポンプ握よ゙かくけん器用モーター8. ギャーポン プと混合箱をつなぐパイプ9.混合箱々せきとの間の 水路 10.調節せき 11. 計量ポンプ 12. ギャーボッ クスのチェンジ ホイール 13 . ボール バルブ 14.7 ロントチャンバー 15. でんぷんを入れるポッパー 16. スラリーミキサー 17. スラリーミキサーのオー パーフローパイプ 18. スラリーミキサーのオーバ 一フローパイプ 19. 牛脂タンク 20. 牛脂ポンプ 21. チェンジ ホイールギャーボックスの出力シャフ ト 22.バランスビーム23. チェインのポッパー 24 . 把8り用チェイン 25. チェイン ホイール 26. チェ イン ホイールの減速ギャー 27.チェイン ホイール 運転用可とう性シャフト 28. チェンジホィールのギ ヤーボックス (副) 29. チェイン貯蔵箱 30 . バラン スビームスイッチ 31 . ワレー 32. 送り出し筒用振 動子 33. 送り出し筒 34. ホッパー用振動子

$<$ 尉斗〉 


\section{I. 染色 仕上}

連続高圧漂白一発展と実験; S. Poser, Textil-Praxis, 504 507 (1966-7)<抄録 6, No. 11, 567(1966)>

ポリエステル緎維のテクスチャード織物の染色につい

て; Text. World, 124〜128 (1966-8)

ポリエステル絨維のテクスチャード編物を染色して 確実によい結果を得るには，いかにすればよいか，て れは Jefferies Southern Processors Inc. の直面し た問題であった。本報で壮, 当社でのその問題の解決 策について簡明に説明し,さらに, ポリェステルテ クスチャード織物の将来についても述へている。

〈尉斗〉

向上したポリエステルの染色； B. Kerres Text. Ind., 85 90 (1966-8)<抄録 6, No. 11，574 (1966)〉

カルバミン酸仕上げ剤による綿織物の耐塩絮性におよ ほす化学的因子; A.H. Reine 他, Amer. Dyest. Rep., $41 \sim 94, \quad 153 \sim 156(1966-9-12)<$ 抄録 6, No. 12, 612 (1966)>

セルロースの架橋; R. Allscher 他, Text. Ind., 144 〜150, $162(1966-9)$

綿織物を 3 種類の典型的な環状尿素誘導体のメチロ ール化合物, ジメチローループロピレン尿素, ジメチ ロールーエチレン尿素的よびジメチロールージヒドロキ シェチレン 尿素を用いて仕上げ処理をし，てれらの 酸扣よびアルカリ溶液に対する挙動を試験した。てれ らの各試験での成績の変化から, 仕上げ工程に依存す る3つの化合物のちがいを測定した。

遊離酸で膨潤状態にあるセルロースの架橋仕ジメチ ロールージヒドロキシェチレン尿素を用いた場合に最 大の效果を示し，との効果の大きさ忳その他のもので はぞんな条件にしても得られなかった。

膨潤していない状態でのセルロースの架橋恀触媒酸 の濃度を実用の濃度にしたとを，ジメチローループロ ピレン尿素扣よびジメチロールーエチレン尿素にくら べて有利である。との差異は架橋した織物をアフター ウオッシングの前と後とでその乾しわ角の比較を測定 すれば顕著である。このセルロースに対する反応機構 のちがいを明らかにするために触媒酸（この場合塩 酸)の濃度を種々に変え, ジメチロール化合物の水溶 液て織物を处理し，その乾しわ角を測定した。

$<$ 三浦 $>$

\section{I. 最終堅品の㹂造と更正}

フロッキング法でカーペット，外衣用織物の㱔造;

C. C. Kantner, Amer, Dyest. Rep., 26 30 (1966-9 -26）<抄録 6, No. 12, 621 (1966)>

種々の切断模型のもとでの緎維長(本数)分布の変化;

J. D. Tallant 他, Text. Res. J., 729 737 (1966-8) 一様な棒の集団ある以緎維集団の切断に対する $2 つ$ の基礎的な模型が議論されたもので, ランダム切断に ついての数学的解析が行なわれたものである。すなわ ち

ランダム切断に扣いて

$F(x)$ )入力としての長さ分布, $\pi(x)$ =切断関数, $G(x)=$ 出力そしての長さ分布, $\alpha=$ lost-lnds モデ ルの $\pi(x)$ 中の係数 $\beta=$ paved end モデルの $\pi(x)$
中の係数, ことに lost ends とは棒の切断後, 切断端 の1つがその糸から除去されたもので, paved ends は切断後切断棒の両端が残り，出力に表われる。李た 1 は $x$ についての微分を表わす.

(1) lost-ends モデルに颃いては

i ) $F(x), \pi(x)$ が与えられたときの $G(x)$ は $G^{\prime}(x)=F^{\prime}(x)+\int_{x}^{\infty} \frac{\pi(y) F^{\prime}(y)}{y} \mathrm{dy}-\pi(x) F^{\prime}(x)$

ii ) $F(x), G(x)$ が与えられたときの $\pi(x)$ は $\pi(x)=\frac{[G(x)-F(x)]-x\left[G^{\prime}(x)-F^{\prime}(x)\right]}{x F^{\prime}(x)}$

iii） $n$ 段階，マルコフ過程では

$$
J\left(\alpha_{i}, n, x\right)=1-[1-F(x)] \pi_{i-1}^{n}\left(1-\alpha_{i} x\right)
$$

ことに $J\left(\alpha_{i}, n, x\right)$ は $n$ 段階の切断後の出力としての 長さ分布.

(2) saved ends モデルに倾いては

i ) $F(x), \pi(x)$ が与えられたときの $\mathrm{G}(x)$ は $Z G(x)=F(x)+2 x \int_{x}^{\infty} \frac{\pi(y)}{y} F^{\prime}(y) \mathrm{dy}$

$$
+\int_{o}^{n} \pi(y) F^{\prime}(y)^{0} \mathrm{dy}
$$

ことに $Z=1+\int_{0}^{\infty} \pi(y) F^{\prime}(y) \mathrm{dy}$

ii ) lost-ends 切断之 saved ends 切断間の関係

$$
\begin{aligned}
& G(x)=F(x)+\alpha(x) \int_{x}^{\infty} \frac{F^{\prime}(y)}{y} \mathrm{dy} \\
& \alpha=\frac{2 \beta}{1+\beta}
\end{aligned}
$$

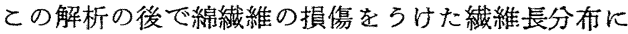
応用した例がのっている。

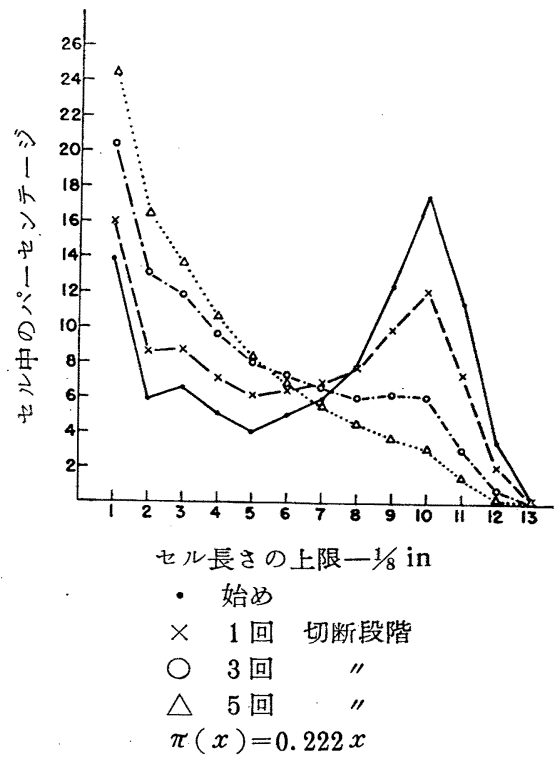

繰り返し切断後の綿の長さ分布の变化

〈鈴木>

\section{F. 工場 管}

工業的に使用される代表的活性斉の生化学的分解; R, A. Conway 他, Amer. Dyest. Rep., 33〜40 (1966-8-1) 
一般活性剂が放流され，いろいろの問題が扣きてい る現在，とれら活性剤をバクテリヤ発酵して分解する てとがでをれば，河川などの水質改良に大をい影響を もつととになる, 本研究は主として活性化泥バクテリ ヤを使用して放流された活性剂を分解する各種の方法 について述べたのの゙，てれがためには使用する活性 剤が普通のバクテリヤの食用になるか否か, また各種 外界条件で適用できるか々いら問題であって一般的に 線状の第 2 級アルコールの活性剤はバクテリヤ酸化で 容易に消失するが，アルキルフェノール系の活性㓮は 困難である、な把第 2 級アルコールでも分岐したもの は反応が扣そい欠点がある。
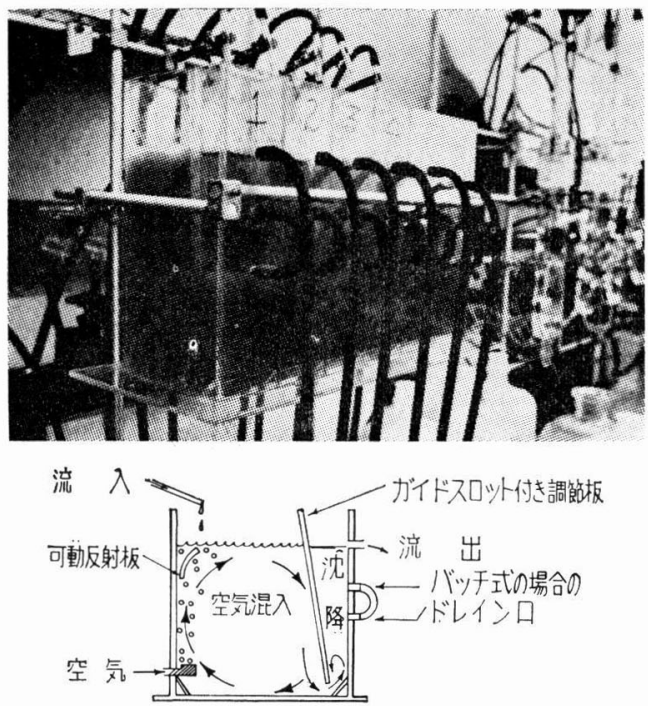

連続またはパッチ式の場合の調整用生物学的熟成槽 〈長野〉
$\overline{\mathrm{A.} \text { 雜 }}$

アフリカの緎維産業 I ; A. Rauchfuss, TextilPraxis, 610 612 (1966-8)

10年来 “衣料モード”の变遷がアフリカ国民の生活 感情に持続的に侵入している. 近年アフリカの繊維外 の製造分野では繊維産業, 特に紡績や織布分野に投じ られたはどの大きな資本投資がなされたととはない。 瀻維設備についてはすでに近く過剩生産を予想される 声もある.しかしこの考えはそんなに問題ではない, それは種々の工場設備が製造計画に対して広く分散さ れて把り, 瀻維工場が多くの需要を満たすためにはな 把状態の置換が必要である.アフリカ国家は発展中で あり, 特に繊維分野では自発的発展した, この点原料 源を有することがよい条件であった．アフリカの絨維 市場は継続的に増加して把り1948から 1960年で 21 億 $\mathrm{m}^{2}$ Кなった, これは主として綿布で 18 億より 27 億に 羊毛は 1 億台で減少に, レイヨンは 1 億から 8 億に, 合縅布は 0 只 1 億となって报り, この内自家生産は 綿が $29 \%$ より $49 \%$ に, 毛は41\%より $71 \%$ K, レイヨン

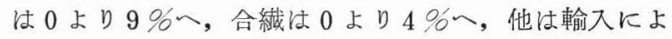
っているなど数字によってアフワカ全体の㵶維工業の 状況を, 炏に北アフリカのアラブ連合, スーダン, リ ビヤ, チュニス, モロッコ,アルジェリア，6加国の それぞれの状況を説明した。

〈篠田〉

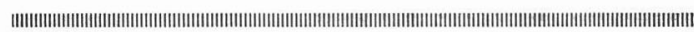
この欄には, 多くの会員からの要望に応えて海外交献 を紹介する．海外資料編集委員会編集による「海外繊維 文献抄録」(1966-11，12）のうちより，比較的重要と 思われる研究論文に類するものを選択して掲載した。お た題目のみ所載のるのは「海外繊維技術文献集」に揭載 予定の\&のである.

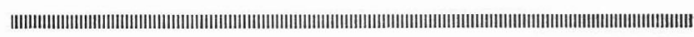

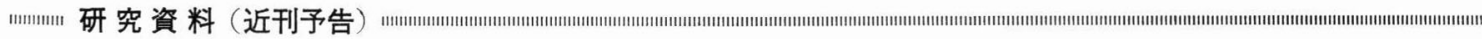

$$
\text { 海外の新しい紡績方式（オープンェンドスピニングを中心として） }
$$

○チェコスロバキヤのオープンエンド紡績 Text. Rec., (1966-6)

。チェコスロバキヤのオープンエンド精紡機による糸と織物 Text. Rec., (1966-8)

。チェコスロバキヤの新しいスピニングシステムでの系むら Text. Manuf., (1966-4)

。スライバーの平均䋳維長をきめる新しい方法 Text. Res. J., (1966-8) 。開綿における自動化 Text. Ind., (1966-4) 。高速 梳 綿 Text. Ind., (1966-7) 。糸切れが多すぎないか Text. Ind., (1966-9) 準梳毛方式の採用による $50 \%$ のコスト ダウン ….................................... Text. World, (1966-5) 。新しいカード Amer. Text. Rep., (1966-4-14) ○耐熱性ナイロン紡績の自動 Bale-to-sliver カーディング Text. World, (1966-6) ニットデニットの概況 Skinn. Rec., (1966-2)

○リング精紡機のあとをつぐ革新紡績法 Text. Rec., (1966-7) 。回転フラットカード用改良供給方式 Text. Rec., (1966-9) 。原綿落下供給方式のカード Text. Rec., (1966-9)

。綿カードにおけるガーネットワイヤと針布の角度について Ind. Text., (1965-10) 